\title{
Carbon Nanostructures: Covalent and Macromolecular Chemistry
}

Francesco Giacalone, $M^{a}$ Ángeles Herranz, and Nazario Martín

\section{1 \\ Introduction}

The aim of this introductory chapter is to bring to the attention of the readers the achievements made in the chemistry of carbon nanostructures and, mostly, in the chemistry of fullerenes, carbon nanotubes (CNTs), and the most recent graphenes. Since the discovery of fullerenes in 1985 and their further preparation in multigram amounts, the chemistry and reactivity of these molecular carbon allotropes have been well established. Actually, this chemical reactivity has been used as a benchmark for further studies carried out in the coming carbon nanotubes (single and multiple wall) and graphenes. Assuming that the fundamental chemistry of fullerenes is known and basically corresponds to that of typical electron-deficient alkenes, we have mainly focused on the chemistry of fullerene-containing polymers. In this regard, the combination of the unique fullerenes with the highly versatile polymer chemistry has afforded a new and interdisciplinary field in which the resulting architectures are able to exhibit unprecedented properties. The basic knowledge of this important topic of macromolecular chemistry of fullerenes nicely complements the following chapters devoted to their supramolecular chemistry.

The chemistry of CNTs, on the other hand, is considerable less developed than that of fullerenes, and most of their studied reactions are generally based on those previously studied on fullerenes. Therefore, despite the recent reviews and books published on CNTs, we feel that an introductory chapter describing the most significant solubilization/derivatization covalent and noncovalent methods should be helpful and welcome by the readers, and particularly to those nonexperts in the field. This same objective has been pursued for the most recent and planar graphenes. The available literature on the chemistry of these one-atom thickness carbon allotropes is considerably less developed. Therefore, some useful chemical procedures reported so far for the functionalization and solubilization of graphenes thus allowing its manipulation and application for the construction of devices - have also been included at the end of the chapter. 
1.2

\section{Fullerene-Containing Polymers}

Since the achievement of [60]fullerenes in ponderable amounts [1], its combination with macromolecular chemistry provided an opportunity to generate new fullerenecontaining polymers, with potential for a broad scope of real applications since it merges $\mathrm{C}_{60}$ properties with the ease and versatile processability and handling of polymers. This approach prompted chemists to design and develop synthetic strategies aimed to obtain even more complex and fascinating novel fullerene-based architectures with unprecedented properties that have been recently reviewed [2]. In fact, chemists are now able to tailor at will a polymeric backbone possessing $\mathrm{C}_{60}$ moieties in such way as to achieve peculiar properties of the final macromolecular material. In this way, block copolymer with well-defined donor-acceptor domains within the diffusion path of electron are created for solar devices [3], or water-soluble biocompatible and biodegradable polymers are designed in order to carry fullerene in circulation for photodynamic cancer therapy purposes [4]. These recent achievements are only the tip of the iceberg of a growing field in which almost all the materials display outstanding properties such as optical limiting [5], or photoinduced electron transfer [6] just to name a few. In addition, polyfullerenes have been successfully employed as active materials not only in electroluminescent devices [7] but also in nonvolatile flash devices [8], and in membranes both for gas separation [9] and for proton exchange fuel cells [10].

The many types of polymeric fullerene derivatives may be classified according to their structural features. As a criterion for the classification, polyfullerenes can be ordered as a function of their increasing chemical complexity and the difficulty to synthesize them, and other interesting classes of nondiscrete multifullerene-containing hybrid materials may also be included in this classification (Figure 1.1).

All-fullerene polymers are specifically those materials or structures that are constituted exclusively by fullerene units covalently linked to each other [11]. These "intrinsic polymers" are prepared simply by exposing pure fullerene to visible light [12], high pressure [13], electron beam [14], and plasma irradiation [15] without control or care for the final structure. Recently, it has been shown that unbound and bound states of $\mathrm{C}_{60}$ molecules can be reversibly controlled at the single-molecule level in ultrathin films of all- $\mathrm{C}_{60}$ polymers using a tip of a scanning tunneling microscope at RT, thus allowing single-molecule-level topochemical digital data [16].

Heteroatom-containing polymers have metals or elements other than carbon inserted in between two $\mathrm{C}_{60}$ moieties. In 1994, Forró discovered that the fulleride phases $\mathrm{AC}_{60}(\mathrm{~A}: \mathrm{K}, \mathrm{Rb}, \mathrm{Rb}$ or $\mathrm{Cs})$, undergo $[2+2]$ cycloadditions producing polyfullerenes with alkali metals in the crystal voids [17]. For the organometallic polymers, the metal doping of $\mathrm{C}_{60}$ leads to the formation of the corresponding charge transfer polymer [18]. Several different metals have been employed in the polymerization with fullerenes, but among them palladium led to the most promising copolymers with outstanding properties [19]. In fact, the polymer $\left(\mathrm{C}_{60} \mathrm{Pd}_{3}\right)_{n}$ has been able to catalyze heterogeneous hydrogenation reactions of alkenes [20]. Very 


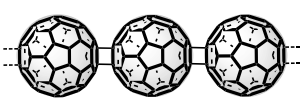

All Carbon

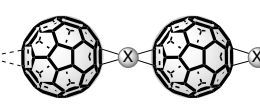

Heteroatom

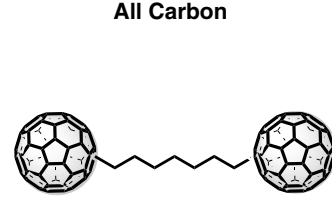

End-capped
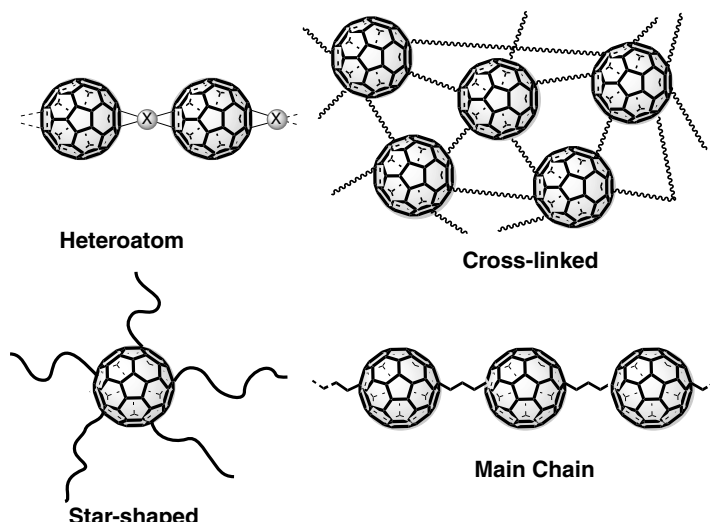

Cross-linked

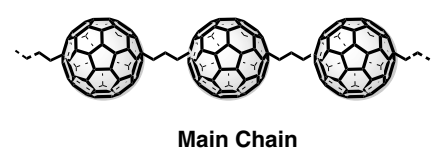

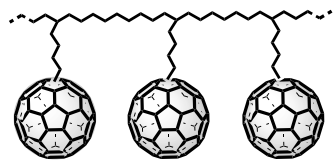

Side Chain

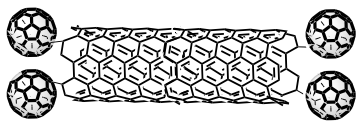

$\mathrm{C}_{60}$-Nanotube Hybrid
38

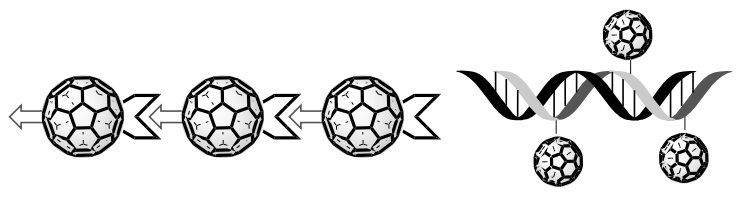

Supramolecular

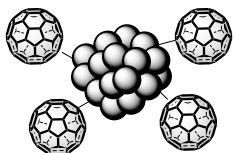

$\mathrm{C}_{60}$-Au Nanoparticles
$C_{60}$-DNA Hybrid

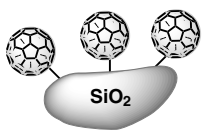

$C_{60}$-Silica Hybrid

Figure 1.1 Classification of the different types of $\mathrm{C}_{60}$-containing polymers and $\mathrm{C}_{60}$-hybrid materials.

recently, 1D "zigzag" polymers have been achieved by mixing fullerene with the oxidizing superacid $\mathrm{AsF}_{5}$ [21]. As a result, a polyfullerenium salt in the solid state has been prepared, with $\mathrm{C}_{60}{ }^{2+}$ units connected by an alternating sequence of fourmembered carbon rings $([2+2]$ cycloaddition) and single $\mathrm{C}-\mathrm{C}$ bonds stabilized by $\mathrm{ASF}_{6}{ }^{-}$anions in the lattice.

Cross-linked $C_{60}$ polymers are synthesized from random and quick reactions that proceed in three dimensions with the help of the fullerene topology. Nevertheless, some extent of control of the addition reactions to the 30 fullerene double bonds is required in order to avoid a drastic intractability of the final products. This class of polymers can be prepared by four main pathways (Figure 1.2):

a) $\mathrm{C}_{60}$ or a $\mathrm{C}_{60}$ derivative and a monomer are mixed together and allowed to react randomly.

b) A multisubstituted $\mathrm{C}_{60}$ derivative is homopolymerized in three dimensions.

c) A preformed polymer properly functionalized at the end termini is allowed to react with $\mathrm{C}_{60}$ or a multisubstituted $\mathrm{C}_{60}$ derivative.

d) Polymers endowed with pending reacting moieties are allowed to react with $\mathrm{C}_{60}$. 
$4 \mid 1$ Carbon Nanostructures: Covalent and Macromolecular Chemistry
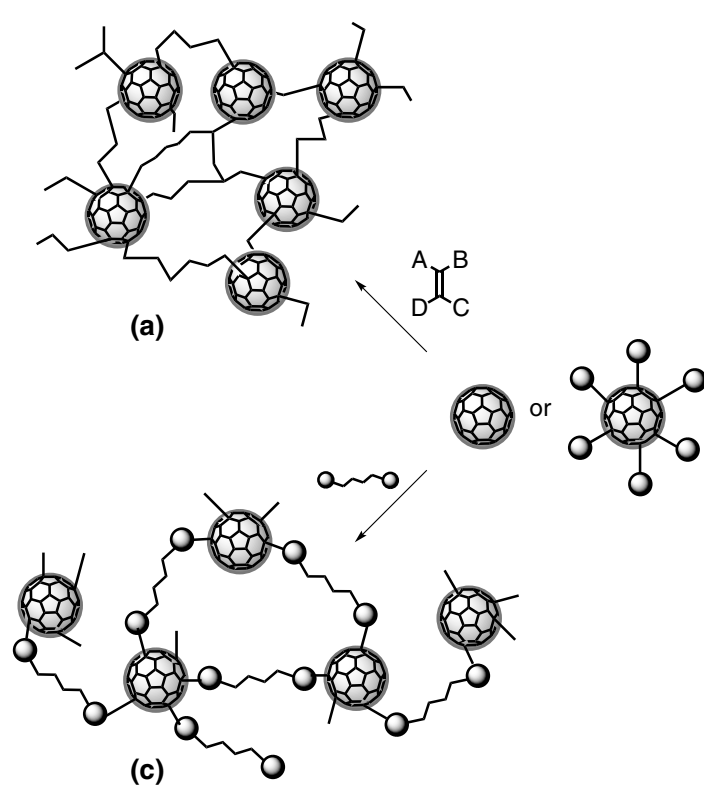

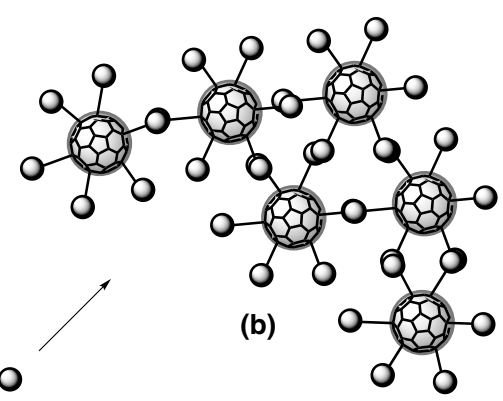

(b)

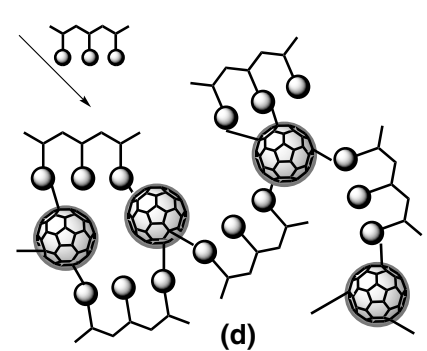

Figure 1.2 Strategies for the synthesis of $\mathrm{C}_{60}$ cross-linked polymers.

Although cross-linked polymers are rather intractable materials, even in this family of polyfullerenes there exist some interesting and useful examples: random fullerene-containing polystyrenes (PS) [22] and poly(methylmethacrylate) [23] showed outstanding nonlinear optics. Nevertheless, cross-linked fullerene-containing polyurethanes displayed third-order NLO response with one-two orders of enhancement in comparison with other $\mathrm{C}_{60}$ derivatives [24]. But the very "revenge" of this family against all the other processable $\mathrm{C}_{60}$ polymers stems from a novel approach described recently by Cheng and $\mathrm{Hsu}$, which will create an organic photovoltaics revolution [25]. They generated in situ a robust cross-linked $\mathrm{C}_{60}$ polymer (1, Figure 1.3), which permits to sequentially deposit the active layer avoiding interfacial erosion. The inverted solar cell ITO/ZnO/1/P ${ }_{3} \mathrm{HT}$ :PCBM/PEDOT:PSS/ Ag showed an outstanding device with a characteristic power conversion efficiency (PCE) of $4.4 \%$ together with an improved cell lifetime with no need for encapsulation.

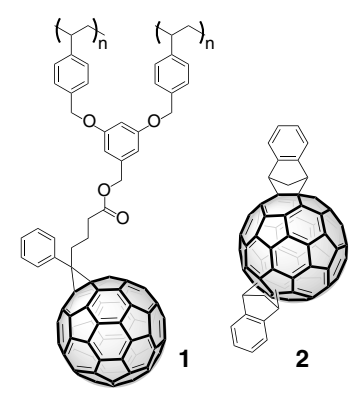

Figure 1.3 Cross-linked polymers used in solar cells. 
(a)

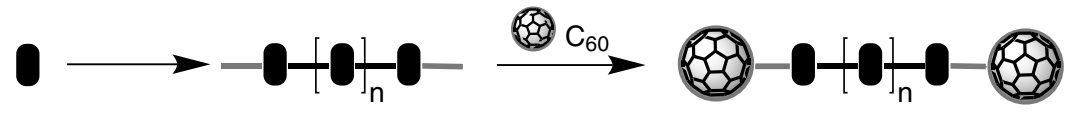

Monomer

Polymer

$\mathrm{C}_{60}$-End-capped Polymer

(b)

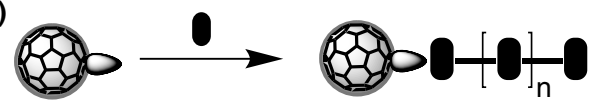

Figure 1.4 Strategies for the synthesis of $\mathrm{C}_{60}$ end-capped polymers.

Some months later, the same group reported the performance of a solar cell obtained employing fullerene bis-adduct 2 in a device with architecture ITO/ZnO/1/P3HT:2/ PEDOT:PSS/Ag achieving the impressive value of $6.22 \%$ efficiency, which retains $87 \%$ of the magnitude of its original PCE value after being exposed to ambient conditions for 21 days [26].

End-capped polymers, also called telechelic polymer, represent a clear example in which the introduction of only one or two units of $\mathrm{C}_{60}$ in the terminal positions of the polymeric backbone may strongly influence both molecular and bulk behavior of well-established polymers. In fact, the presence of fullerene moieties at the end of the polymeric chain can modify the hydrophobicity of the parent polymer and, subsequently, its properties. Two different synthetic strategies have been followed in order to prepare these polymers (Figure 1.4):

a) "grafting to": the polymer is synthesized first, followed by incorporation of fullerenes.

b) "grafting from": the polymeric chain is grown from a $\mathrm{C}_{60}$ derivative as the starting material.

In the past years, water-soluble end-capped polymers are finding applications not only as radical scavengers [27], antitumor agents, in photodynamic cancer therapy (PDT) [28] but also as compatibilizer between the donor polymer and the fullerene acceptor in organic solar cells [29].

Star-shaped $C_{60}$ polymers, also known as "flagellenes," are composed of 2- to 12long and flexible polymer chains directly linked to a fullerene moiety resembling sea stars. So far, their syntheses have been carried out by following two different synthetic pathways, analogously to end-capped polymers (Figure 1.5):

a) The "graft-to" approach, in which preformed polymers are linked to the fullerene unit.

b) The "graft-from" approach, in which the polymeric chains grow from the surface of properly functionalized fullerene derivatives.

In the past years, water-soluble and biodegradable star-shaped $\mathrm{C}_{60}$-poly(vinyl alcohol) [30] and star-shaped [31] poly(vinylpyrrolidone) proved to be effective as photosensitizers to produce singlet oxygen resulting in good candidates for PDT. Also, a star-shaped PEG-C ${ }_{60}$ showed good singlet oxygen generation and low toxicity 
6 6 1 Carbon Nanostructures: Covalent and Macromolecular Chemistry

(a)

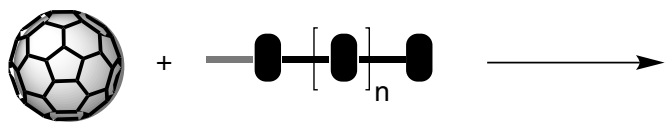

(b)
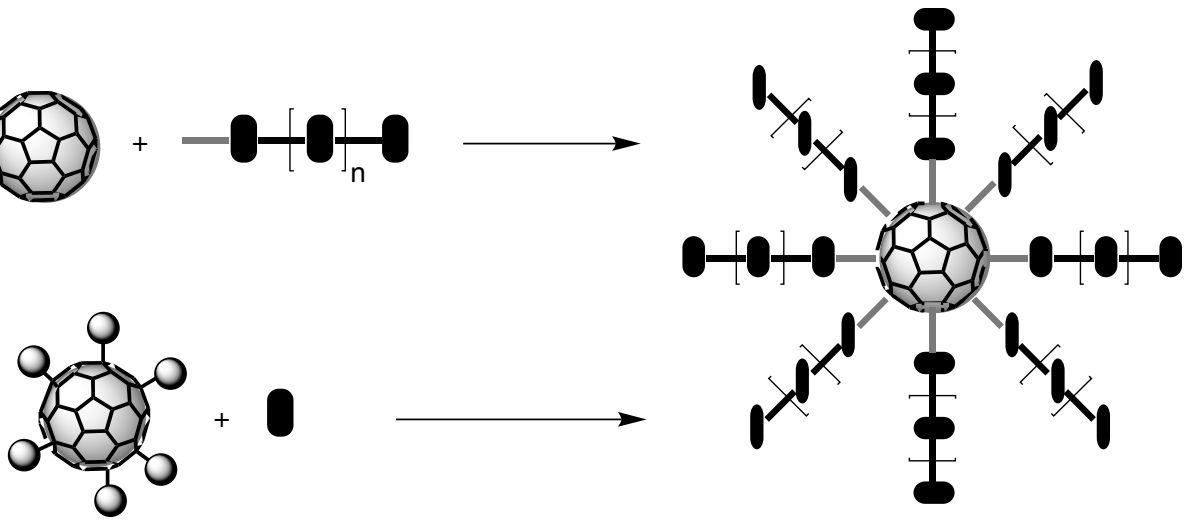

$\mathrm{C}_{60}$-Star-shaped Polymer

Figure 1.5 Strategies for the synthesis of $\mathrm{C}_{60}$ star-shaped polymers.

against human promonocytic THP-1 cells, and could find application in the treatment of multidrug-resistant pathogens [32].

In the main-chain polymers, also called in-chain or pearl necklace, $\mathrm{C}_{60}$ units are directly allocated in the polymer backbone forming a necklace-type structure. Unfortunately, double addition to the $\mathrm{C}_{60}$ sphere affords a complex regioisomeric mixture (up to eight isomers) besides the formation of cross-linking products by multiple additions. Main-chain polymers are prepared by following three different synthetic strategies (Figure 1.6):

a) A direct reaction between the $\mathrm{C}_{60}$ cage and a suitable symmetrically difunctionalized monomer;

(a)

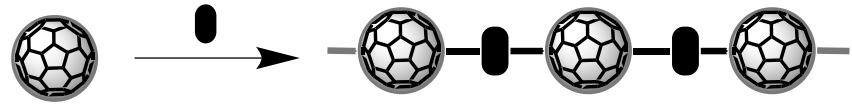

(b)

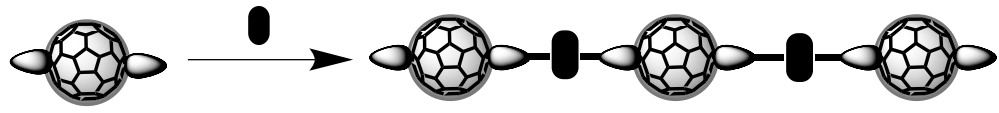

(c)

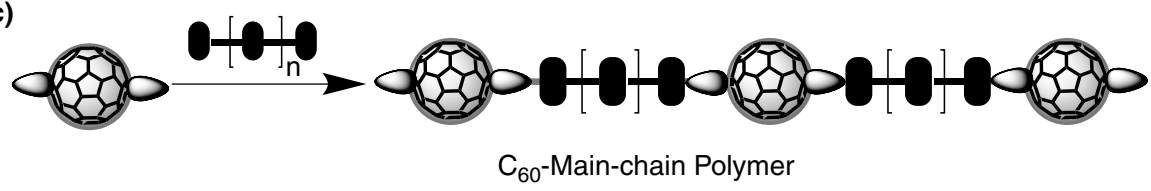

Figure 1.6 Strategies for the synthesis of $C_{60}$ main-chain polymers. 

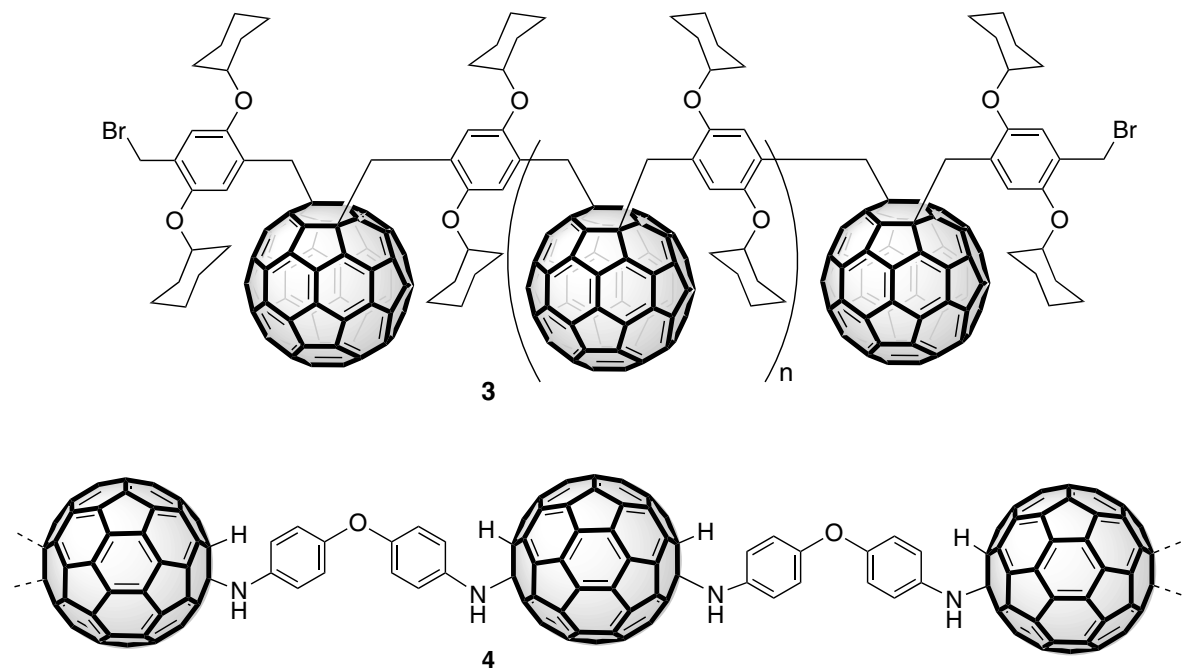

Figure 1.7 1,4-Connected in-chain polymer 3 and water-soluble polyrotaxane 4.

b) A polycondensation between a fullerene bis-adduct (or a mixture) and a difunctionalized monomer;

c) Reaction between $\mathrm{C}_{60}$ or a fullerene bis-adduct and a linear polymer difunctionalized at both ends.

In 2009, 1,4-connected in-chain polymer 3 (Figure 1.7) worked well in nonoptimized photovoltaic devices showing the remarkable conversion of light efficiency of $1.6 \%$ [33]. On the other hand, water-soluble polyrotaxane 4 has been successfully employed as a highly efficient DNA-cleaving agent under visible light conditions (Figure 1.7) [34].

Side-chain polymers are the most "populated" family of $\mathrm{C}_{60}$ polymers, also called on-chain or "charm-bracelet," with a wide range of potential applications. In this family are also included the "double-cable" polymers [35], in which the $\pi$-conjugated semiconducting polymer (p-type cable) with electron-donating characteristics is endowed with covalently connected electron-accepting fullerene units able to interact among themselves (n-type cable), thus forming a "double-cable" with a priori remarkable advantages for construction of photovoltaic devices.

Although in the literature a large number of examples have been reported, the synthetic strategies followed for the preparation of side-chain polymers can be summarized as only two different approaches (Figure 1.8):

a) Direct introduction of fullerene itself or a $\mathrm{C}_{60}$ derivative into a preformed polymer.

b) Synthesis of a $\mathrm{C}_{60}$ derivative that can be, in turn, directly homopolymerized or copolymerized together with other monomer(s). In the case of double-cable polymers, monomer electropolymerization is also possible. 
(a)

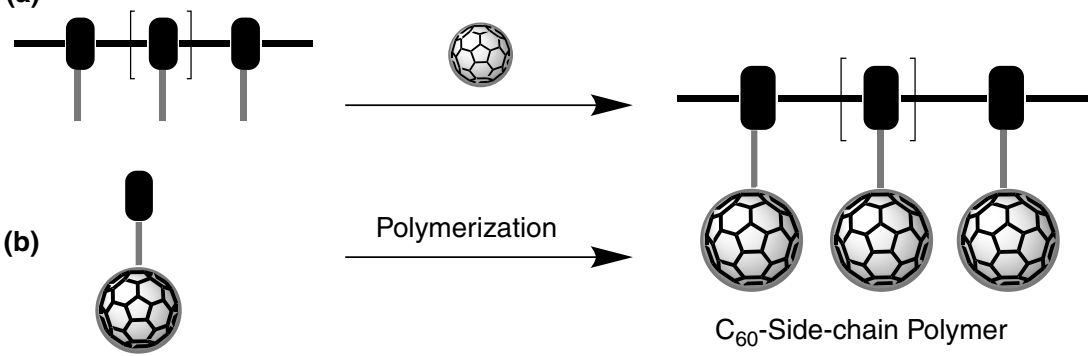

Figure 1.8 Strategies for the synthesis of side-chain $\mathrm{C}_{60}$ polymers.

In this family, the knowledge gathered during a century of studies on polymers has been used to bind $\mathrm{C}_{60}$ to all of the "classic" families of polymers such as polystyrenes [36], polyacrylates [37], polyethers [38], polycarbonates [39], polysiloxanes [40], polyvinylcarbazoles [41], and polysaccharides [42] in the search for improved processability and enhanced properties, with a wide range of potential applications. In the past years, much attention has been devoted to fullerene-containing side-chain block copolymers, especially for their use in solar cells, thanks to their natural tendency to self-assemble into periodic ordered nanostructures [43]. Moreover, they can be employed in diverse manners to control the final material morphology. A number of $\mathrm{C}_{60}$-containing block copolymers have been prepared and their morphological organization [44], as well as their performances in solar cells [45], has been reported.

Supramolecular $C_{60}$ polymers will be discussed in detail in Chapter 8 . To date, four synthetic strategies have been followed in order to prepare $\mathrm{C}_{60}$ supramolecular polymers, as shown in Figure 1.9:

a) Systems obtained by interactions between functionalized polymers and $\mathrm{C}_{60}$ derivatives or fullerene itself;
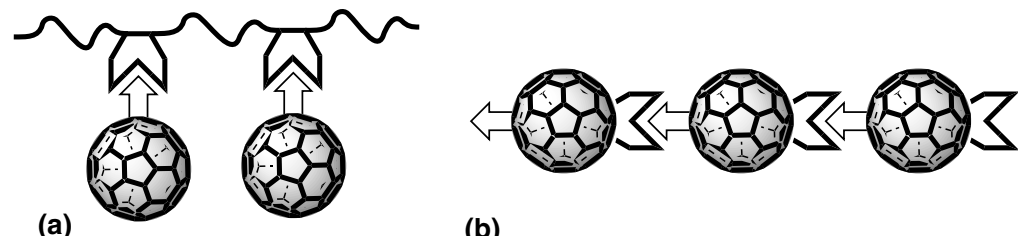

(a)

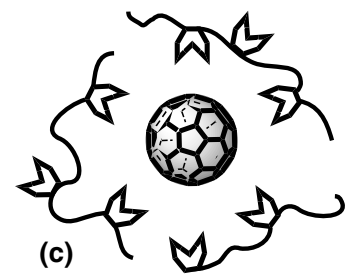

(b)

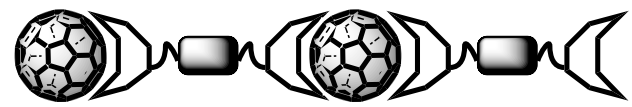

(d)

Figure 1.9 Different forms of $\mathrm{C}_{60}$ supramolecular polymers. 
b) Assembly of self-complementary $\mathrm{C}_{60}$ derivatives;

c) Multisubstituted fullerene derivatives and complementary polymeric backbones;

d) Assemblies between ditopic concave guests and $\mathrm{C}_{60}$ by means of concave-convex complementary interactions.

Besides the above-mentioned well-established classes of fullerene polymers, a series of polydisperse nondiscrete hybrid materials with a huge potential for real applications is emerging.

Fullerene-DNA hybrids have been studied since 1994 [46], but recently are experiencing a new momentum due to their application as gene delivery agents [47]. Two different strategies have been followed in order to conjugate DNA with fullerenes:

1) The supramolecular complexation: since DNA may be regarded as an anionic polyelectrolyte, it can form complexes with positively charged fullerene derivatives.

2) The covalent binding of $\mathrm{C}_{60}$ at the end of a polynucleotide chain.

Carbon nanotube-fullerene hybrids were first discovered serendipitously by Luzzi in 1998 who found that several $\mathrm{C}_{60}$ units, by-products in the synthesis of single-walled carbon nanotubes (SWCNTs), were trapped inside the open-ended nanotubes, forming quasi-1D arrays called "peapods" [48]. Since then, these kinds of aggregates have been extensively studied and a series of endohedral and functionalized hollow fullerenes have been introduced in the inner space of nanotubes and have been investigated [49]. Besides the peapods, fullerene-CNT hybrids have been prepared both via supramolecular or covalent methods. To date five strategies have been disclosed for the combination of the two allotropes (Figure 1.10):

(a)

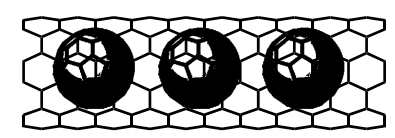

(c)

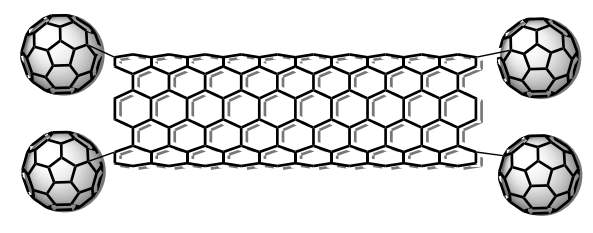

(e)

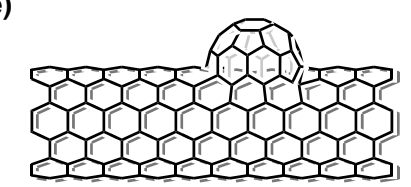

(b)

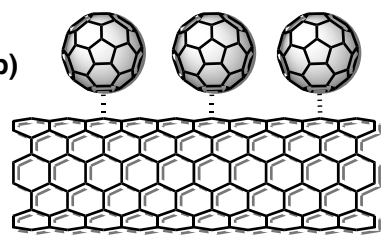

(d)

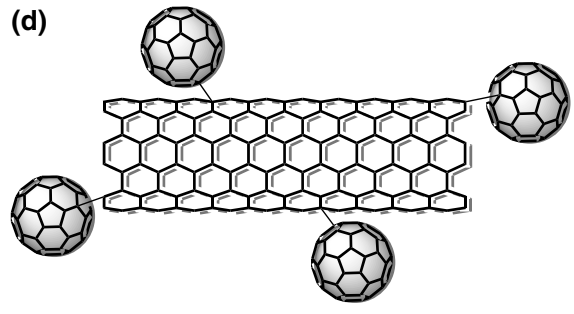

Figure 1.10 Types of $\mathrm{C}_{60}-\mathrm{CNT}$ hybrids. 
$10 \mid 1$ Carbon Nanostructures: Covalent and Macromolecular Chemistry

a) The supramolecular filling of the void space of CNTs with hollow fullerene or endohedral derivatives both pristine or functionalized;

b) Supramolecular interaction between $\mathrm{C}_{60}$, or its derivatives, and the sidewall of CNTs;

c) The covalent derivatization of the external rims of CNTs;

d) The covalent random derivatization of the side-wall and rims of CNTs;

e) The covalent fusion of $\mathrm{C}_{60}$ onto the CNTs surface.

The external supramolecular linking has been achieved through $\pi-\pi$ interactions using fullerene derivatives endowed with pyrene moieties [50], while the covalent linking has been carried out both at the ending rims [51] and at the wall level [52]. In 2007 were synthesized nanobuds, carbon nanostructures in which fullerene moieties are fused on the outer wall of the nanotube [53].

Other covalent hybrids between two different allotropes of carbon have also been reported such as a $\mathrm{C}_{60}$-diamond hybrid prepared by deposition of evaporated fullerene onto the bare-diamond surface [54] or the synthesis and characterization of a graphene-fullerene hybrid [55].

Fullerene-gold nanoparticles (Au NP) were first prepared in 1998 [56]. Since then, several groups have been engaged in the synthesis of these hybrid systems in their search for new exotic properties. Their synthesis has been carried out employing three main approaches:

a) The supramolecular linking of $\mathrm{C}_{60}$ to $\mathrm{Au}$ NP;

b) The covalent linkage of fullerene or its derivatives on surface-functionalized $\mathrm{Au} \mathrm{NP}$;

c) Direct in situ electroreductive self-assembly between $\mathrm{C}_{60}{ }^{2-}$ and a gold precursor.

In the first approach, electrostatic [57] and complementary supramolecular interactions have been exploited [58], while in the second the nucleophilic addition of amines to a fullerene double bond has been the reaction of choice [59]. Alternatively, disulfide-containing fullerene derivatives have been successfully anchored onto gold NP surface [60]. Finally, the $\mathrm{C}_{60}$ dianion has been used to reduce tetrachloroauric acid obtaining three-dimensional fullerene bound gold nanoclusters [61].

\section{3}

\section{Carbon Nanotubes}

The extensive research carried out on CNTs during the past years has shown the unprecedented mechanical, electrical, and thermal properties that these macromolecules exhibit [62]. Of the wide range of carbon nanostructures available [63], CNTs stand out as truly unique materials that have caused a noteworthy impact on fields such as field-effect transistors (FETs), light-emitting diodes (LEDs), organic solar 
cells (OSCs), biochemical sensors, memory elements or additives in composite materials [64].

However, most CNT applications require manipulation, interaction, or bonding of CNTs to other materials, in solution or in high-viscosity matrices. These operations are often hindered by the chemical inertness of the CNT surface and by the large aggregates that the tubes form due to $\pi-\pi$ stacking interactions. The chemical modification of the CNT surface is an approach generally used to overcome some of these problems [65].

In general, CNT functionalization can be divided into different categories [66]: the covalent attachment of functional entities onto the CNT scaffold that can take place at the termini of the tubes and/or at the sidewalls; the noncovalent interaction of organic and inorganic moieties with the carbon nanotube surface by the use of varying interaction forces such as van der Waals, charge transfer, and $\pi-\pi$ interactions, and the special case of the endohedral filling of CNTs with atoms or small molecules (see previous section for the endohedral filling with fullerenes). In the following paragraphs, we will briefly introduce the recent advances in the covalent modification of CNTs toward the creation of multifunctional materials since the noncovalent modification of CNTs will be addressed in detail in chapters 11 to 13 .

\subsection{1}

\section{Defect Functionalization}

Among the different surface functionalization techniques, oxidation of CNTs is probably the most widely studied. The treatment of the crude material under strong acidic and oxidative conditions, such as sonication in a mixture of concentrated $\mathrm{HNO}_{3}$ and $\mathrm{H}_{2} \mathrm{SO}_{4}$, or heating in a mixture of $\mathrm{H}_{2} \mathrm{SO}_{4} / \mathrm{H}_{2} \mathrm{O}_{2}$, results in the formation of short opened tubes with oxygenated functions (carbonyl, carboxyl, hydroxyl, etc.) mostly at the edges of the CNTs [67]. This approach represents a popular pathway for further modification of the nanotubes since the acid functions can react with alcohols or amines to give ester or amide derivatives (Figure 1.11).

In one of the first examples, Haddon and coworkers [68] reported the functionalization of SWCNTs, with octadodecylamine (ODA) to produce the corresponding SWCNT-ODA amide 5. The introduction of long hydrocarbon chains increases the solubility of the SWCNT-ODA in organic solvents, assisting its characterization and facilitating the obtainment of highly purified SWCNT-based materials that are suitable for physical property measurements. To increase the water solubility of SWCNTs, the same group described the covalent functionalization with poly ( $m$-aminobenzene sulfonic acid) (PABS) (6) via an amide link [69]. The conductivity of the SWCNT-PABS copolymer was much higher than that of the parent PABS.

The solubilization of SWCNTs associated with biomolecules in both aqueous and organic solutions has been investigated at considerable length. The biomolecules employed in the functionalization of SWCNTs include simple saccharides and polysaccharides, peptides, proteins, lipids, enzymes, or DNA and RNA [62f]. For 
12 1 Carbon Nanostructures: Covalent and Macromolecular Chemistry

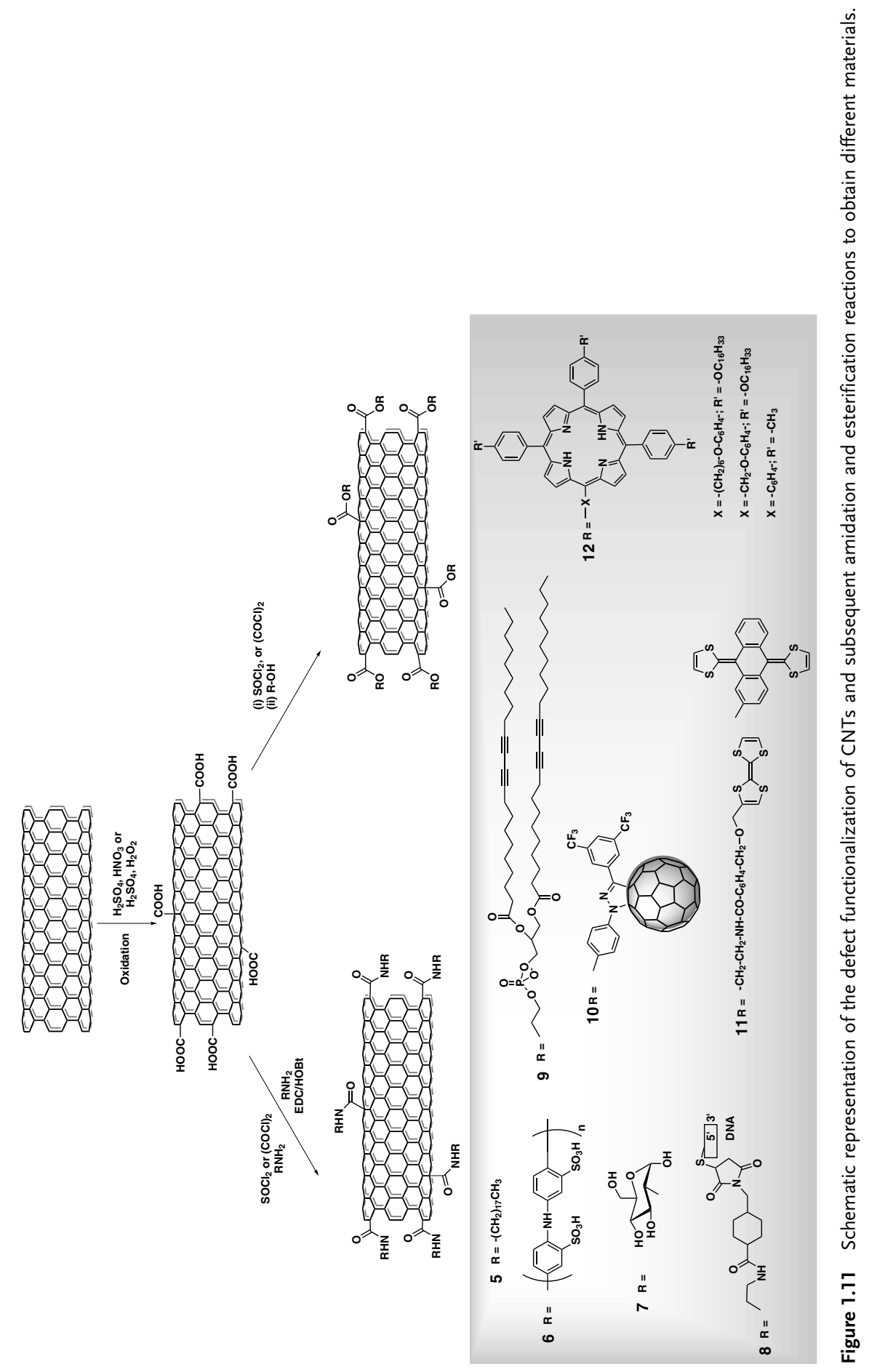


example, considering the method developed by Pompeo and Resasco reported the coupling of glucosamine to acyl chloride-activated nanotubes (7) [70]. The solubility in water of the conjugates formed ranged from 0.1 to $0.3 \mathrm{mg} / \mathrm{ml}$, depending on temperature. The preparation of covalent nanoconjugates of DNA and SWCNTs (8) was carried out by Baker et al. [71]. The high stability and accessibility in hybridization experiments indicates that DNA chains are chemically bound to the exterior surface of SWCNTs and not wrapped around or intercalated within the nanotubes. These DNA-SWCNT adducts hybridize selectively with complementary sequences, with only minimal interactions with mismatched sequences. Other biomolecules of interest are lipids, which have also been covalently linked to SWCNTs in the search for novel biosensor systems (9 in Figure 1.11) [72].

The development of reliable and reproducible methodologies to integrate CNTs into functional structures such as donor-acceptor hybrids, able to transform sunlight into electrical or chemical energy, has emerged as an area of intensive research [73]. In this context, recently the synthesis of the first conjugated hybrid SWCNT-[60] fullerene materials (10) has been described, considering the reaction of amines with SWCNTs functionalized in their rims with acyl chlorides [51]. The authors decorated the SWCNTs with fragments of $N$-anilinopyrazolino[60]fullerene and with the aid of vibrational spectroscopy and high-resolution transmission electron microscopy (TEM) corroborated the existence of [60]fullerene units located at the rims of the SWCNTs. Considering a similar strategy, Martín and coworkers [74] described an efficient way to functionalize SWCNTs with the strong electron donor tetrathiafulvalene (TTF) or its $\pi$-extended analogue (exTTF) derivatives (11). The procedure implies the reaction of SWCNT-COOH with TTF or exTTF-based compounds, through esterification or amidation reactions. This work depicts the preparation of the first TTF-SWCNTdonor-acceptor systems to evaluate the possible use of CNTs in solar energy conversion applications. The analysis of these compounds by different analytical, spectroscopic, and microscopic (TEM) techniques confirmed the presence of TTF or exTTF units connected to the SWCNTs. Photophysical studies by timeresolved spectroscopy revealed the presence of radical ion species $\left(\mathrm{TTF}^{\bullet+}\right.$, exTTF ${ }^{\bullet}$, and $\mathrm{SWCNT}^{\circ-}$ ) indicating the existence of an efficient photoinduced electron transfer (PET), a critical requirement to prepare photovoltaic devices. The covalent attachment of porphyrin units to SWCNTs (12) has also been investigated by several groups in an attempt to emulate the natural photosynthesis [75]. For example, Li et al. [75a] reported that quenching of the fluorescence of the porphyrin units was strongly dependent on the length of the spacer between the nanotube and the chromophore. In fact, a better interaction between the nanotube and the porphyrin was observed for longer and more flexible alkyl chains.

\subsection{2}

\section{Sidewall Functionalization}

As outlined in the previous section, a defect functionalization-based chemical attachment of organic moieties on CNTs will primarily proceed at the nanotube tips. As a consequence, the functionalization degree will be relatively low as the huge 
surface area of the CNT sidewall is hardly involved in the transformation sequence. Indeed, the direct chemical alteration of the CNT sidewall is a challenging task due to the close relationship of the CNT $s p^{2}$ carbon network with planar graphite and its low reactivity. In contrast to the esterification or amidation reactions of the acid groups of oxidized SWCNTs, the functionalization of the sidewalls of CNTs requires the use of highly reactive species.

Historically, based on the low reactivity of the CNT sidewall, direct sidewall addition of elemental fluorine was one of the first successful alterations of the $s p^{2}$ carbon framework [76]. During the past decade, a variety of pathways leading to fluorinated carbon nanotubes have been developed, and fluorinated nanotubes have become a widely used starting material for further chemical transformation steps, based on the nucleophilic substitution of fluorine atoms. For example, Barron and coworkers have shown that the reaction of fluorinated HiPco SWCNTs (13) with $\omega$-amino acids leads to water-soluble SWCNT derivatives (14) [77]. In addition, the solubility in water is controlled by the length of the hydrocarbon chain of the amino acid and does strongly depend on the $\mathrm{pH}$ value of the solution. Kelly and coworkers have prepared thiol- and thiophene-functionalized SWCNTs (14) - which allow a subsequent coupling of the tubes to gold nanoparticles - via the reaction of bifunctional amines with fluorinated CNTs (13) [78].

Another useful methodology is the one introduced by Tour in 2001, where aryl radicals are generated from diazonium salts via one-electron electrochemical reduction [79] or considering a solvent-based thermally induced reaction with the in situ generation of the diazonium compound by reacting aniline derivatives with isoamyl nitrite (Figure 1.12, 15) [80].

Cycloaddition reactions have attracted the interest of a great number of scientists and remarkable examples on the functionalization of the sidewalls of carbon nanotubes by means of carbene [81] or nitrene [82] additions, Bingel reaction [83], or Diels-Alder cycloadditions [84] have been reported. Although, probably the most commonly used sidewall derivatization reaction is the 1,3-dipolar cycloaddition of azomethine ylides, generated by the condensation of an $\alpha$-amino acid and an aldehyde (Figure 1.13) [85].

Since this method was reported, a large variety of CNT derivatives have been described, and it is especially important to remark on the relevant development achieved in the field of drug design and discovery based on CNT derivatives [86]. Prato's methodology has allowed to synthesize water-soluble CNTs bearing pendant ammonium groups $\left(\mathrm{NH}_{3}{ }^{+}\right.$-SWCNT) [87], which were tested in biocompatibility and cellular interaction studies, where different cells were cultured in the presence of these CNT derivatives. The ammonium-functionalized CNTs were observed by TEM microscopy and localized inside the cells [88]. In other appealing example, radioactive-labeled carbon nanotubes were intravenously injected in mice and found to be excreted in urine [89], showing that water-soluble CNTs can be well-tolerated in vivo, while exhibiting an exceptional capacity to cross cell membranes and localize into the cytoplasm.

Water-soluble CNTs have also been used to efficiently complex and translocate DNA inside cells in the pioneering studies exploring the ability of CNTs to deliver 


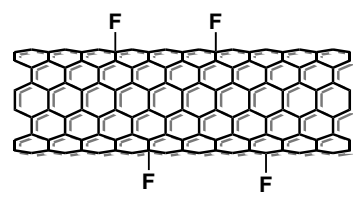

13

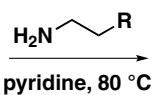

3h
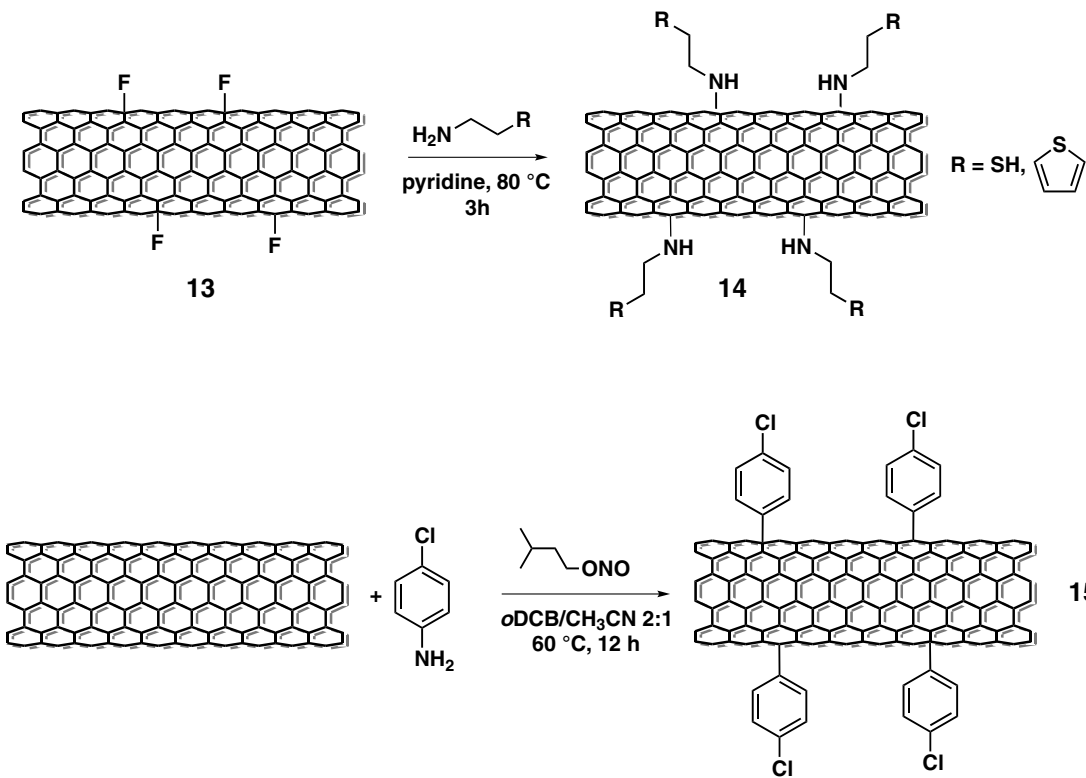

15

Figure 1.12 Radical additions and nucleophilic substitutions on the sidewall of CNTs.

genes [86]. Furthermore, CNTs were functionalized with antibiotics (Amphotericin B) by Prato's reaction showing a promising activity, even on strains usually resistant to Amphotericin B [90]. CNTs bearing methotrexate - a potent anticancer agent - have been synthesized as well by using this methodology. Preliminary results demonstrated that these CNT derivatives are, at least, as active as the methotrexate alone [91].

Although the chemical functionalization has brought about an important advance in the preparation and processing of CNTs, still the essential challenge is to control the degree of functionalization at the different levels that various applications require. In this sense, Hirsch and coworkers have recently reported a method that could be particularly useful for controlling the extent of chemical modification of CNTs (Figure 1.14).

The first step of the process is to covalently attach alkyl groups to the sidewalls of SWCNTs, following a reaction sequence that consists in the nucleophilic addition of
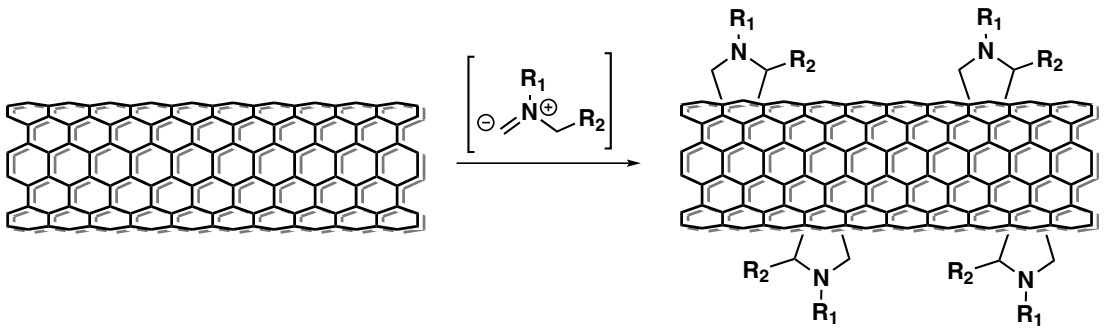

Figure 1.13 1,3-Dipolar cycloaddition of azomethine ylides. 

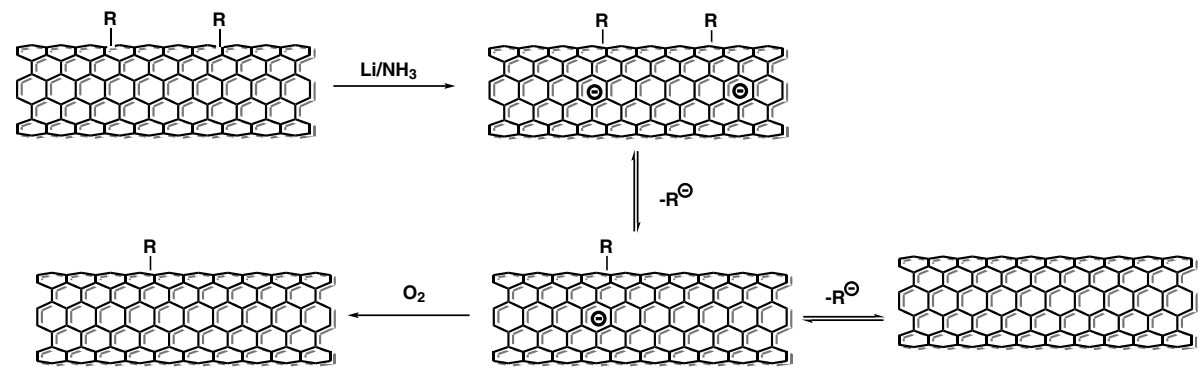

Figure 1.14 Reductive retrofunctionalization of SWCNTs $(\mathrm{R}=n \mathrm{Bu}, n \operatorname{PrNH})$.

alkyllithium derivatives to the sidewalls of CNTs and subsequent reoxidation of the intermediate $\mathrm{R}_{n}-\mathrm{CNT}^{n-}$ [92]. Subsequently, the highly functionalized SWCNTs were treated with sodium or lithium metals in liquid ammonia and the appended alkyl groups could be released, after donation of electrons from the metal to the SWCNTs. More interestingly, some of the alkyl groups could be replaced by $n$-propyl amino groups by simply adding $n$-propylamine to the reaction mixture [93]. In addition to controlling the functionalization degree, this protocol allows the attachment of two different chemical groups to the surface of SWCNTs.

\section{4}

\section{Graphenes}

Since the first report on the mechanical isolation of graphene from graphite, the interest in the physical properties and potential applications of the youngest member of the family of carbon nanostructures has led to an unprecedented increase in the number of publications on its synthesis, properties, and applications [94]. The revolution is going further, if possible, since in October 2010 the Nobel Prize for Physics was awarded to Andre Geim and Konstantin Novoselov for their work on these unique 2D macromolecules [95].

Graphenes offer important properties such as high elasticity, electric conductivity, or spin transport, and at the same time are free of some of the drawbacks that still hamper the implementation of SWCNTs in technological applications, such as the presence of metal catalyst impurities [96]. However, before one can chemically manipulate graphenes they have to be chemically exfoliated into individual or fewlayer sheets and be stabilized. Typical methodologies for the production of graphene are direct sonication, chemical reduction, mechanical exfoliation, or exfoliation of graphite into individual sheets by stabilization through interactions with solvents [97].

Once obtained, the functionalization of graphenes is achieved by employing covalent or noncovalent methodologies similar to the ones used for CNTs, to make them tractable in different solvents and to decorate graphenes with different functional groups that can add new properties to the material. 


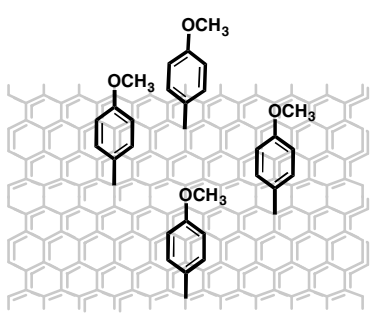

16

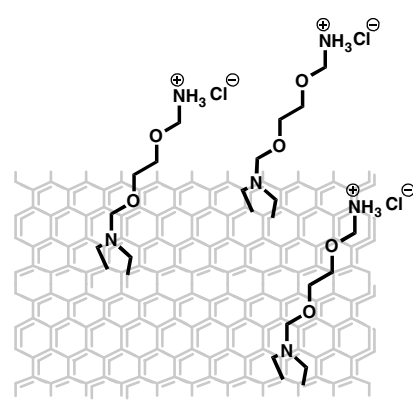

17

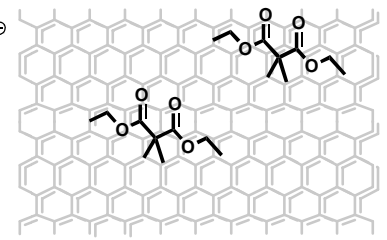

18

Figure 1.15 Covalently functionalized few-layer graphenes with diazonium salts (16), azomethyne ylides (17), or bromomalonates (18).

\subsection{1}

\section{Covalent Functionalization}

By using a covalent strategy, Haddon and coworkers [98] have reported an efficient method to obtain graphene sheets functionalized with long hydrocarbon chains (Goctadodecylamine, G-ODA). Oxidative treatment of microcrystalline graphite with nitric and sulfuric acids produces oxidized graphite (GO), decorated with carboxylic groups at the edges. The presence of these acidic functionalities provide a way to introduce long hydrocarbon chains that assist the solubilization of the graphene sheets in polar solvents, which is a fundamental issue in order to improve graphite processability.

In a similar approach, Tour and coworkers [99] have recently reported the functionalization of single graphene sheets using aryl diazonium salts (16, Figure 1.15). These graphene sheets were in turn produced via surfactant-wrapped chemically converted graphene nanosheets, and obtained from reduction of graphene oxide with hydrazine. The authors studied these new carbon nanomaterials by different spectroscopic and microscopic techniques, and the results proved an efficient functionalization, allowing the nanosheets to be dissolved in organic solvents.

In a recent work, graphenes produced by dispersion and exfoliation of graphite in $\mathrm{N}$-methylpyrrolidone or in benzylamine have been successfully functionalized by using the 1,3-dipolar cycloaddition of azomethine ylides under thermal conditions (17, Figure 1.15) [100] or following a Bingel reaction under microwave irradiation (18, Figure 1.15) [101]. The graphenes incorporating pyrrolidine rings, which also bear an amino functional group, bind selectively to gold nanorods that served as contrast markers for the identification of the reactive sites and produce a hybrid material that can be useful for various applications.

\subsection{2}

\section{Noncovalent Functionalization}

Graphene can be functionalized using noncovalent methods such as wrapping with surfactants or ionic liquids [94a]. Water-soluble graphenes have been obtained with 
surfactants such as polyoxyethylene(40)nonylphenylether (Igepal CO-890), sodium dodecylsulfate (SDS) or cetyltrimethylammonium bromide (CTAB) [102]. The onestep electrochemical approach for the preparation of ionic liquid-functionalized graphite sheets has also been explored in the search for water-soluble graphenes, which in addition can be exfoliated into functionalized graphene nanosheets [103].

However, the graphene produced today is mostly going into composites that benefit from its mechanical, electronic, or optical properties [94]. Mechanical reinforcement can be achieved when graphene is dispersed with polyacrylonitrile nanofibers [104], or in poly(methyl methacrylate) (PMMA) [105]. Ramanathan et al. reported that an addition of approximately $1 \mathrm{wt} \%$ of graphene to PMMA leads to increases in the elastic modulus of $80 \%$ and in the tensile strength of about $20 \%$. In a comparative study, these researchers demonstrated that among all the nanofiller materials considered, single-layer functionalized graphene provide the best results [106]. For electronic applications, graphene offers fewer problems with uncontrollable variety from batch to batch than does CNT synthesis and, it has been combined with different polymers in the search for materials with improved electronic properties. In this sense, Bai et al. modified graphenes with conjugated polymer sulfonated polyaniline (PANI) and investigated its electrochemical activity [107]. Pluronic copolymers (poly-(ethylene oxide)-block-poly(propylene oxide)block-poly(ethylene oxide) were also employed as solubilizing agents for graphenes to form a supramolecular hydrogel [108]. The optical applications of graphene composites offer the advantage of a relatively easy processing condition of films [94d]. Recently, Rao et al. prepared graphenes dispersed in a polymer matrix that proved to be highly effective saturable absorbers - optical elements used in modelocking of laser, based on their properties to exhibit optical loss at high optical intensity [109].

The interactions between graphene and a series of small aromatic molecules have also been investigated in detail. For example, the $\pi-\pi$ interactions with pyrene derivatives (i.e., pyrene butanoic acid succidymidyl ester 19, Figure 1.16) helped to stabilize graphene in aqueous solutions [110].

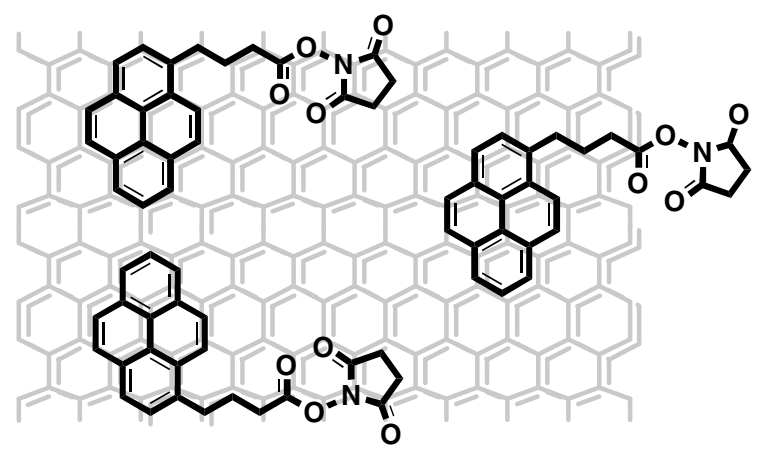

19

Figure 1.16 Noncovalent interactions between graphenes and the pyrene butanoic acid succidymidyl ester 19. 
In addition, different electroactive molecules have been found to interact with the graphene surface by $\pi-\pi$ stacking interactions and form donor-acceptor complexes by using 1-pyrene-1-sulfonic acid sodium salts and the disodium salt of 3,4,9,10perylenetetracarboxylic diimide bisbenzenesulfonic acid [111]. The negative charges in both molecules act as stabilizing species to maintain a strong static repulsion force between the negative-charged graphene sheets in solution, giving rise to durable monolayers. More interestingly, the noncovalent modification of graphene films with pyrene derivatives improves the hydrophilic characteristics, work function, and power conversion efficiency in photovoltaic cells [112]. The PCE of organic solar cells fabricated with the supramolecularly modified graphene increases from $0.21 \%$ for the unmodified films to $1.71 \%$ for anodes using the pyrene-modified graphene, which paves the way for the substitution of ITO in photovoltaic and electroluminescent devices with low-cost graphene films.

Molecular doping has turned out to be an important tool to tailor the electronic properties of graphene. The interaction of graphene with electron donors (aniline or tetrathiafulvalene, TTF) and electron acceptors (nitrobenzene or tetracyanoethylene, TCNE) caused marked changes in the electronic structure of graphene [113]. Thus, the Raman G band of few-layer graphene is softened in the presence of aniline or TTF, and strengthened with electron acceptor molecules such as nitrobenzene and TCNE. In addition, charge transfer bands are found in the visible region when TTF and TCNE interact with few-layer graphene [114]. The electrical conductivity of graphene also varies on interaction with both types of electroactive molecules: electron donor molecules decrease the conductivity of graphene, while electron acceptor molecules increase the conductivity. In addition, the magnitude of the interaction depends on the surface area of the graphene samples [115]. However, recent work has demonstrated that graphene can be electronically decoupled from the electroactive molecules adsorbed on it when grown on a metallic surface of $\operatorname{Ir}(111)$ [116]. Under such conditions, the selforganization of the molecules $7,7^{\prime}, 8,8^{\prime}$-tetracyano-p-quinodimethane, TCNQ, and 2,3,5,6-tetrafluoro-7,7',8,8'-tetracyano-p-quinodimethane ( $\mathrm{F}_{4}$-TCNQ) is guided by the intermolecular interaction, attractive for TCNQ and repulsive for $F_{4}$ TCNQ [116].

So far, all the investigations on molecular doping have been carried out in the solid state and only recently, Hirsch and coworkers have reported the binding and electronic interaction of graphene with an organic dye molecule 20 (Figure 1.17) in homogeneous solution [117].

Although perylene bisimides exhibit strong fluorescence, no emission background is present in the Raman spectrum of a dispersion of turbostatic graphite with 20 in $N$-methylpyrrolidone, which indicates a pronounced quenching due to the electronic communication with graphene. The interaction between 20 and graphene was further corroborated by titration experiments, where the quantum yield of the graphene-titrated perylene solution was reduced by $65 \%$ compared to pristine perylene solutions [117]. These results demonstrated that the noncovalent functionalization of graphene in organic solvents could be a useful approach for the systematic tuning of the electronic properties of graphenes. 


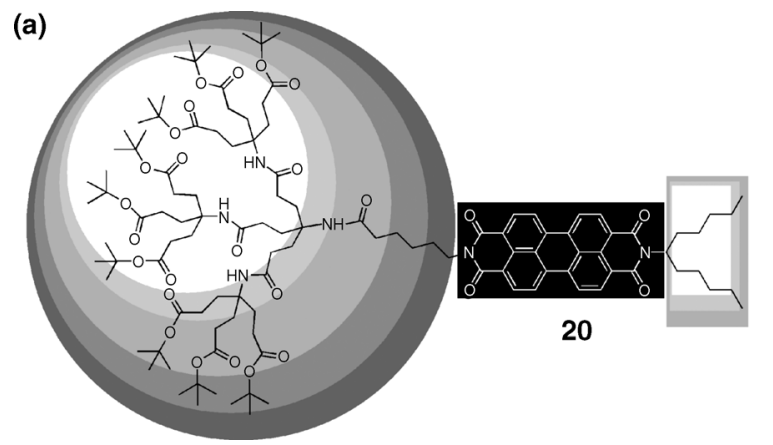

(b)

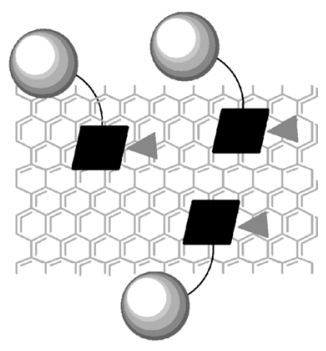

Figure 1.17 (a) Dendronized perylene bisimide 20 and (b) cartoon representing the noncovalent binding of $\mathbf{2 0}$ to graphene.

1.5

\section{Summary and Conclusions}

As stated at the outset, the goal of this chapter is to summarize the most important achievements in the covalent and macromolecular chemistry of fullerenes in order to have a better understanding of the chemistry of these molecular carbon allotropes, thus nicely complementing the following chapters devoted to supramolecular chemistry. Furthermore, both CNTs and graphenes have been considered in this chapter and, therefore, the most significant functionalization/solubilization methods known so far have also been presented.

Importantly, covalent functionalization is typically accompanied by a significant damage to the electronic structure of the carbon nanostructures. Therefore, the relevance of the supramolecular methods available so far is significantly emphasized in the following chapters of the book.

Needless to say, for a more comprehensive knowledge of the nowadays very rich chemistry of fullerenes, CNTs, and graphenes, the reader is encouraged to go to the many reviews and books available in the chemical literature mentioned in this book.

\section{Acknowledgments}

This work has been supported by the MICINN of Spain (CT2008-00795 and Consolider-Ingenio CSD2007-00010 on Molecular Nanoscience) and Comunidad de Madrid (MADRISOLAR-2, S2009/PPQ-1533).

\section{References}

1 Kratschmer, W., Lamb, L.D., Fostiropoulos, K., and Huffman, D.R. (1990) Nature, 347, 354-358.

2 (a) Giacalone, F. and Martín, N. (2006) Chem. Rev., 106, 5136-5190; (b) Giacalone, F. and Martín, N. (2010) Adv. Mater., 22, 4220-4248;

(c) Giacalone, F. and Martín, N. (2009) Fullerene Polymers: Synthesis, Properties and Applications, 
Wiley-VCH Verlag GmbH, Weinheim, Germany.

3 Charvet, R., Acharya, S., Hill, J.P., Akada, M., Liao, M., Seki, S., Honsho, Y., Saeki, A., and Ariga, K. (2009) J. Am. Chem. Soc., 131, 18030-18031.

4 (a) Stoilova, O., Jérôme, C., Detrembleur, C., Mouithys-Mickalad, A., Manolova, N., Rashkov, I., and Jérôme, R. (2006) Chem. Mater., 18, 4917-4923; (b) Stoilova, O., Jérôme, C., Detrembleur, C., MouithysMickalad, A., Manolova, N., Rashkov, I., and Jérôme, R. (2007) Polymer, 48, 1835-1843.

5 Ma, B., Riggs, J.E., and Sun, Y.-P. (1998) J. Phys. Chem. B, 102, 5999-6009.

6 Chen, Y., Huang, Z.-E., Cai, R.-F., Yu, B.-C., Ito, O., Zhang, J., Ma, W.-W., Zhong, C.-F., Zhao, L., Li, Y.-F., Zhu, L., Fujitsuka, M., and Watanabe, A. (1997) J. Polym. Sci. B Polym. Phys., 35, 1185-1190.

7 (a) Cloutet, E., Fillaut, J.-L., Gnanou, Y., and Astruc, D. (1994) J. Chem. Soc. Chem. Commun., 2433-2434; (b) Fedurco, M., Costa, D.A., Balch, A.L., and Fawcett, W.R. (1995) Angew. Chem. Int. Ed. Engl., 34, 194-196; (c) Chen, X., Gholamkhass, B., Han, X., Vamvounis, G., and Holdcroft, S. (2007) Macromol. Rapid Commun., 28, 1792-1798; (d) Nanjo, M., Cyr, P.W., Liu, K., Sargent, E.H., and Manners, I. (2008) Adv. Funct. Mater., 18, 470-477.

8 Ling, Q.-D., Lim, S.-L., Song, Y., Zhu, C.-X., Chan, D.S.-H., Kang, E.-T., and Neoh, K.-G. (2007) Langmuir, 23, 312-319.

9 (a) Sterescu, D.M., Bolhuis-Versteeg, L., van der Vegt, N.F.A., Stamatialis, D.F., and Wessling, M. (2004) Macromol. Rapid Commun., 25, 1674-1678;

(b) Sterescu, D.M., Stamatialis, D.F., Mendes, E., Wibbenhorst, M., and Wessling, M. (2006) Macromolecules, 39, 9234-9242;

(c) Vinogradova, L.V., Polotskaya, G.A., Shevtsova, A.A., and Alentev, A.Y. (2009) Polym. Sci. Ser. A, 51, 209-215.

10 Wang, H., DeSousa, R., Gasa, J., Tasaki, K., Stucky, G., Jousselme, B., and Wudl, F. (2007) J. Membr. Sci., 289, 277-283.
11 For detailed treatises on this topic:

(a) Special issue on polymeric fullerenes (1997) Appl. Phys. A Mater. Sci. Process., 64 (3); (b) Sundqvist, B. (1999) Adv. Phys., 48, 1-416; (c) Blank, V.D., Buga, S.G., Dubitsky, G.A., Serebryanaya, N.R., Yu Popov, M., and Sundqvist, B. (1998) Carbon, 36, 319-343.

12 Rao, A.M., Zhou, P., Wang, K.-A., Hager, G.T., Holden, J.M., Wang, Y., Lee, W.-T., Bi, X.-X., Eklund, P.C., Cornett, D.S., Duncan, M.A., and Amster, I.J. (1993) Science, 259, 955-957.

13 Iwasa, Y., Arima, T., Fleming, R.M., Siegrist, T., Zhou, O., Haddon, R.C., Rothberg, L.J., Lyons, K.B., Carter, H.L., Hebard, A.F., Jr., Tycko, R., Dabbagh, G., Krajewski, J.J., Thomas, G.A., and Yagi, T. (1994) Science, 264, 1570-1572.

14 Rao, A.M., Eklund, P.C., Hodeau, J.L., Marques, L., and Nuñez-Regueiro, M. (1997) Phys. Rev. B, 55, 4766-4773.

15 (a) Takahashi, N., Dock, H., Matsuzawa, N., and Ata, M. (1993) J. Appl. Phys., 74, 5790-5794; (b) Zou, Y.J., Zhang, X.W., Li, Y.L., Wang, B., Yan, H., Cui, J.Z., Liu, L.M., and Da, D.A. (2002) J. Mater. Sci., 37, 1043-1047.

16 Nakaya, M., Tsukamoto, S., Kuwahara, Y., Aono, M., and Nakayama, T. (2010) Adv. Mater., 22, 1622-1625.

17 (a) Stephens, P.W., Bortel, G., Faigel, G., Tegze, M., Janossy, A., Pekker, S., Oszlányi, G., and Forró, L. (1994) Nature, 370, 636-639; (b) Pekker, S., Forró, L., Mihaly, L., and Janossy, A. (1994) Solid State Commun., 90, 349-351.

18 Rao, A.M., Eklund, P.C., Venkateswaran, U.D., Tucker, J., Duncan, M.A., Bendele, G.M., Stephens, P.W., Houdeau, J.-L., Marques, L., Nuñez-Regueiro, M., Bashkin, I.O., Ponyatovsky, E.G., and Morovsky, A.P. (1997) Appl. Phys. A Mater. Sci. Process, 64, 231-2239.

19 Nagashima, H., Nakaoka, A., Saito, Y., Kato, M., Kawanishi, T., and Itoh, K. (1992) J. Chem. Soc. Chem. Commun., 377-379.

20 Nagashima, H., Nahaoka, A., Tajima, S., Saito, Y., and Itoh, K. (1992) Chem. Lett., 1361-1364. 
$22 \mid 1$ Carbon Nanostructures: Covalent and Macromolecular Chemistry

21 Riccò, M., Pontiroli, D., Mazzani, M., Gianferrari, F., Pagliari, M., Goffredi, A., Brunelli, M., Zandomeneghi, G., Meier, B.H., and Shiroka, T. (2010) J. Am. Chem. Soc., 132, 2064-2068.

22 (a) Bunker, C.E., Lawson, G.E., and Sun, Y.P. (1995) Macromolecules, 28, 3744-3746; (b) Kojima, Y., Matsuoka, T., Takahashi, H., and Karauchi, T. (1995) Macromolecules, 28, 8868-8869;

(c) Kojima, Y., Matsuoka, T., Takahashi, H., and Karauchi, T. (1997) J. Mater. Sci. Lett., 16, 2029-2031.

$23 \mathrm{Lu}$, Z., Goh, S.H., Lee, S.Y., Sun, X., and Ji, W. (1999) Polymer, 40, 2863-2867.

24 (a) Luang, L., Chen, Q., Sargent, E.H., and Wang, Z.Y. (2003) J. Am. Chem. Soc., 125, 13648-13649; (b) Chen, Q., Luang, L., Sargent, E.H., and Wang, Z.Y. (2003) Appl. Phys Lett., 83, 2115-2117;

(c) Chen, Q., Luang, L., Wang, Z.Y., and Sargent, E.H. (2004) Nano Lett., 9, 1673-1678.

25 Hsieh, C.-H., Cheng, Y.-J., Li, P.-J., Chen, C.-H., Dubosc, M., Liang, R.-M., and Hsu, C.-S. (2010) J. Am. Chem. Soc. 132, 4887-4893.

26 Cheng, Y.-J., Hsieh, C.-H., He, Y., Hsu, C.-S., and Li, Y. (2010) J. Am. Chem. Soc., 132, 17381-17383.

27 (a) Kai, W., Hua, L., Dong, T., Pan, P., Zhu, B., and Inoue, Y. (2008) Macromol. Chem. Phys., 209, 104-111; (b) Zhou, G., Harruna, I.I., Zhou, W.L., Aicher, W.K., and Geckeler, K.E. (2007) Chem. Eur. J., 13, 569-573.

28 (a) Liu, J., Ohta, S., Sonoda, A., Yamada, M., Yamamoto, M., Nitta, N., Murata, K., and Tabata, Y. (2007) J. Control. Release, 117, 104-110; (b) Liu, J. and Tabata, Y. (2011) J. Drug. Target., 18, 602-610.

29 Boudouris, B.W., Molins, F., Blank, D.A. Frisbie, C.D., and Hillmyer, M.C. (2009) Macromolecules, 42, 4118-4126.

30 Detrembleur, C., Stoilova, O., Bryaskova, R., Debigne, A., MouithysMickalad, A., and Jérôme, R. (2006) Macromol. Rapid Commun., 27, 498-504.

31 Hurtgen, M., Debuigne, A., Mouithys-Mickalad, A., Jérôme, R., Jérôme, C., and Detrembleur, C. (2010) Chem. Asian J., 5, 859-868.
32 Stoilova, O., Jérôme, C., Detrembleur, C., Mouithys-Mickalad, A., Manolova, N., Rashkov, I., and Jérôme, R. (2007) Polymer, 48, 1835-1843.

33 (a) Hiorns, R.C., Cloutet, E., Ibarboure, E., Vignau, L., Lemaitre, N., Guillerez, S., Absalon, C., and Cramail, H. (2009) Macromolecules, 42, 3549-3558; (b) Hiorns, R.C., Cloutet, E., Ibarboure, E., Khoukh, A., Bejbouji, H., Vignau, L., and Cramail, H. (2010) Macromolecules, 43, 6033-6044.

34 Samal, S., Choi, B.-J., and Geckeler, K.E. (2001) Macromol. Biosci., 1, 329-331.

35 (a) Cravino, A. and Sariciftci, N.S. (2002) J. Mater. Chem., 12, 1931-2159;

(b) Cravino, A. and Sariciftci, N.S. (2003) Nat. Mater., 2, 360-361; (c) Cravino, A. (2007) Polymer Int., 56, 943-956.

36 (a) For some selected example on sidechain polystyrene- $\mathrm{C}_{60}$ polymers: Liu, B., Bunker, C.E., and Sun, T.-P. (1996) J. Chem. Soc. Chem. Commun., 1241-1242. (b) Chen, Y., Huang, Z.-E., Cai, R.-F., Kong, S.-Q., Chen, S., Shao, Q., Yan, X., Zhao, F., and Fu, D. (1996) J. Polym. Sci. A Polym. Chem., 34, 3297-3302; (c) Stalmach, U., de Boer, B., Videlot, C., van Hutten, P.F., and Hadziioannou, G. (2000) J. Am. Chem. Soc., 122, 5464-5472; (d) Cao, T., Wei, F., Yang, Y., Huang, L., Zhao, X., and Cao, W. (2002) Langmuir, 18, 5186-5189.

37 For some selected example on side-chain polyacrylate- $\mathrm{C}_{60}$ polymers:

(a) Zheng, J., Goh, S.H., and Lee, S.Y. (1997) Polym. Bull., 39, 79-84. (b) Zheng, J.W., Goh, S.H., and Lee, S.Y. (2000) J. Appl. Polym. Sci., 75, 1393-1396; (c) Wang, Z.Y., Kuang, L., Meng, X.S., and Gao, J.P. (1998) Macromolecules, 31, 5556-5558; (d) Wang, C., Tao, Z., Yang, W., and Fu, S. (2001) Macromol. Rapid Commun., 22, 98-103.

38 (a) Goh, S.H., Zheng, J.W., and Lee, S.Y. (2000) Polymer, 41, 8721-8724;

(b) Gutiérrez-Nava, M., Masson, P., and Nierengarten, J.-F. (2003) Tetrahedron Lett., 44, 4487-4490.

39 For some selected examples on sidechain polyacarbonate- $\mathrm{C}_{60}$ polymers: (a) Tang, B.Z., Peng, H., Leung, S.M. Au, C.F., Poon, W.H., Chen, H., Wu, X., 
Fok, M.W., Yu, N.-T., Hiraoka, H., Song, C., Fu, J., Ge, W., Wong, G.K.L., Monde, T., Nemoto, F., and $\mathrm{Su}$, K.C. (1998) Macromolecules, 31, 103-108. (b) Wu, H., Li, F., Lin, Y., Cai, R.-F., Wu, H., Tong, R., and Qian, S. (2006) Polym. Eng. Sci., 46, 399-405;

(c) Vitalini, D., Mineo, P., Iudicelli, V., Scamporrino, E., and Troina, G. (2000) Macromolecules, 33 7300-7309.

40 (a) Kraus, A. and Müllen, K. (1999) Macromolecules, 32, 4214-4219; (b) Li, Z. and Qin, J. (2003) J. Appl. Polym. Sci., 89, 2068-2071.

41 (a) Chen, Y., Huang, Z.-E., and Cai, R.-F. (1996) J. Polym. Sci. B Polym. Phys., 34, 631-640; (b) Gu, T., Chen, W.-X., and Xu, Z.-D. (1999) Polym. Bull., 42, 191-196.

42 (a) Okamura, H., Miyazono, K., Minoda, M., and Miyamoto, T. (1999) Macromol. Rapid Commun., 20, 41-45; (b) Ungurenasu, C. and Pienteala, M. (2007) J. Polym. Sci. A Polym. Chem., 45, 3124-3128.

43 Darling, S.B. (2009) Energy Environ. Sci., 2, 1266-1273.

44 (a) Chen, X., Gholamkhass, B., Han, X., Vamvounis, G., and Holdcroft, S. (2007) Macromol. Rapid Commun., 28, 1792-1797; (b) Richard, F., Brochon, C., Leclerc, N., Eckhardt, D., Heiser, T., and Hadziioannou, G. (2008) Macromol. Rapid Commun., 29, 885-891;

(c) Lee, J.U., Cirpan, A., Emrik, T., Russell, T.P., and Jo, W.H. (2009) J. Mater. Chem., 19, 1483-1487; (d) Hu, Z., Zou, J., Deibel, C., Gesquiere, A.J., and Zhai, L. (2010) Macromol. Chem. Phys., 211, 2416-2424.

45 (a) Gholamkhass, B. and Holdcroft, S. (2010) Chem. Mater., 22, 5371-5376; (b) Gholamkhass, B., Peckham, T.J., and Holdcroft, S. (2010) Polym. J., 1, 708;

(c) Yang, C., Lee, J.K., Heeger, A.J., and Wudl, F. (2009) J. Mater. Chem.,

19, 5416-5423; (d) Dante, M., Yang, C., Walker, B., Wudl, F., and Nguyen, T.-Q. (2010) Adv. Mater., 22, 1835-1838.

46 Boutorine, A.S., Tokuyama, H., Takasugi, M., Isobe, H., Nakamura, E., and Hélène, C. (1994) Angew. Chem. Int. Ed. Engl., 33, 2462-2465.
47 (a) Isobe, H., Nakanishi, W., Tomita, N., Jinno, S., Okayama, H., and Nakamura, E. (2006) Chem. Asian J., 1, 167-175; (b) Maeda-Mamiya, R., Noiri, E., Isobe, H., Nakanishi, W., Okamoto, K., Doi, K., Sugaya, T., Izumi, T., Homma, T., and Nakamura, E. (2010) Proc. Natl. Acad. Sci. USA, 57, 5339-5344.

48 Smith, B.W., Monthioux, M., and Luzzi, D.E. (1998) Nature, 396, 323-324.

49 (a) Kitaura, R. and Shinohara, H. (2006) Chem. Asian J., 1, 646-655; (b) Britz, D.A. and Khlobystov, A.N. (2006) Chem. Soc. Rev., 35, 637-659.

50 Guldi, D.M., Menna, E., Maggini, M., Marcaccio, M., Paolucci, D., Paolucci, F., Campidelli, S., Prato, M., Rahman, G.M.A., and Schergna, S. (2006) Chem. Eur. J., 12, 3975-3983.

51 Delgado, J.L., de la Cruz, P., Urbina, A., López Navarrete, J.T., Casado, J., and Langa, F. (2007) Carbon, 45, 2250-2252.

52 Giordani, S., Colomer, J.-F., Cattaruzza, F., Alfonsi, J., Meneghetti, M., Prato, M. and Bonifazi, D. (2009) Carbon, 47, 578-588.

53 (a) Nasibulin, A.G., Pikhitsa, P.V., Jiang, H., Brown, D.P., Krasheninnikov, A.V., Anisimov, A.S., Queipo, P., Moisala, A., Gonzalez, D., Lientschnig, G., Hassanien, A., Shandakov, S.D., Lolli, G., Resasco, D.E., Choi, M., Tománek, D., and Kauppinen, E.I. (2007) Nat. Nanotechnol., 2, 156-161; (b) Nasibulin, A.G., Anisimov, A.S., Pikhitsa, P.V., Jiang, H., Brown, D.P., Choi, M., and Kauppinen, E.I. (2007) Chem. Phys. Lett., 446, 109-114; (c) He, M., Rikkinen, E., Zhu, Z., Tian, Y., Anisimov, A.S., Jiang, H., Nasibulin, A.G., Kauppinen, E.I., Niemelä, M., and Krause, A.O.I. (2010) J. Phys. Chem. C 114, 13540-13545.

54 Ouyang, T., Loh, K.P., Qi, D., Wee, A.T.S., and Nesladek, M. (2008) ChemPhysChem, 9, 1286-1293.

55 (a) Zhang, X., Huang, Y., Wang, Y., Ma, Y., Liu, Z., and Chen, Y. (2008) Carbon, 47, 334-337; (b) Liu, Z.-B., Xu, Y.-F., Zhang, X.-Y., Zhang, X.-L., Chen, Y.-S., and Tian, J.-G. (2009) J. Phys. Chem. B, 113, 9681-9686. 
$24 \mid 1$ Carbon Nanostructures: Covalent and Macromolecular Chemistry

56 Brust, M., Kiely, C.J., Bethell, D., and Schiffrin, D.J. (1998) J. Am. Chem. Soc., 120, 12367-12367.

57 (a) Lim, I.-I.S., Ouyang, J., Luo, J., Wang, L., Zhou, S., and Zhong, C.-J. (2005) Chem. Mater., 17, 6528-6531; (b) Lim, I.-I.S., Pan, Y., Mott, D., Ouyang, J., Njoki, P.N., Luo, J., Zhou, S., and Zhong, C.-J. (2007) Langmuir, 23, 10715-10724; (c) Yin, G., Xue, W., Chen, F., and Fan, X. (2009) Coll. Surface A, 340, 121-125.

58 (a) Liu, J., Alvarez, J., Ong, W., and Kaifer, A.E. (2001) Nano Lett., 1, 57-60; (b) Liu, Y., Wang, H., Chen, Y., Ke, C.-F., and Liu, M. (2005) J. Am. Chem. Soc., 127, 657-666.

59 (a) Shon, Y.-S. and Choo, H. (2002) Chem. Commun., 2560-2561; (b) Sudeep, P.K., Ipe, B.I., Thomas, K.G., George, M.V., Barazzouk, S., Hotchandani, S., and Kamat, P.V. (2002) Nano Lett., 2, 29-35; (c) Geng, M., Zhang, Y., Huang, Q., Zhang, B., Li, Q., Li, W., and Li, J. (2010) Carbon, 48, 3570-3574.

60 Shih, S.-M., Su, W.-F., Lin, Y.-J., Wu, C.-S., and Chen, C.-D. (2002) Langmuir, 18, 3332-3335.

61 Liu, W. and Gao, X. (2008) Nanotechnology, 19, 405609.

62 For recent reviews, see (a) Peng, X. and Wong, S.S. (2009) Adv. Mater., 21, 625-642; (b) Singh, P., Campidelli, S., Giordani, S., Bonifazi, D., Bianco, A., and Prato, M. (2009) Chem. Soc. Rev., 38, 2214-2230; (c) Zhao, Y.-L. and Stoddart, J.F. (2009) Acc. Chem. Res., 42 , 1161-1171; (d) Wang, H. (2009) Curr. Opin. Colloid Interface Sci., 14, 364-371; (e) Eder, D. (2010) Chem. Rev., 110, 1348-1385; (f) Karousis, N., Tagmatarchis, N., and Tasis, D. (2010) Chem. Rev., 110, 5366-5397.

63 Delgado, J.L., Herranz, M.A., and Martín, N. (2008) J. Mater. Chem., 18, 1417-1426.

64 Prato, M. (2010) Nature, 465, 172-173.

65 (a) Reich, S., Thomsen, C., and Maultzsch, J. (2004) Carbon Nanotubes: Basic Concepts and Physical Properties, Wiley-VCH Verlag GmbH, Weinheim, Germany; (b) Popov, V.N. and Lambin, P. (2006) Carbon Nanotubes, Springer,
Dordrecht; (c) Guldi, D.M. and Martín, N. (2010) Carbon Nanotubes and Related Structures, Wiley-VCH Verlag GmbH, Weinheim, Germany; (d) Akasaka, T., Wudl, F., and Nagase, S.

(2010) Chemistry of Nanocarbons, John Wiley \& Sons, Ltd., Chichester, United Kingdom.

66 (a) Hirsch, A. (2002) Angew. Chem. Int. Ed., 41, 1853-1859; (b) Hirsch, A. and Vostrowsky, O. (2005) Top. Curr. Chem., 245, 193-237.

67 Liu, J., Rinzler, A.G., Dai, H., Hafner, J.H., Bradley, R.K., Boul, P.J., Lu, A., Iverson, T., Shelimov, K., Huffman, C.B., Rodriguez-Marcias, F., Shon, Y.-S., Lee, T.R., Colbert, D.T., and Smalley, R.E. (1998) Science, 280, 1253-1256.

68 Hamon, M.A., Chen, J., Hu, H., Chen, Y., Itkis, M.E., Rao, A.M., Eklund, P.C., and Haddon, R.C. (1999) Adv. Mater., 11, 834-840.

69 Zhao, B., Hu, H., and Haddon, R.C. (2004) Adv. Funct. Mater., 14, 71-76.

70 Pompeo, F. and Resasco, D.E. (2002) Nano Lett., 2, 369-373.

71 Baker, S.E., Cai, W., Lasseter, T.L., Weidkamp, K.P., and Hammers, R.J. (2002) Nano Lett., 2, 1413-1417.

72 He, P. and Urban, M.W. (2005) Biomacromolecules, 6, 2455-2457.

73 (a) Guldi, D.M., Rahman, G.M.A., Sgobba, V., and Ehli, C. (2006) Chem. Soc. Rev., 35, 471-487; (b) Guldi, D.M. (2007) Phys. Chem. Chem. Phys., 1400-1420; (c) Sgobba, V. and Guldi, D.M. (2009) Chem. Soc. Rev., 38, 165-184.

74 Herranz, M.A., Martín, N., Campidelli, S., Prato, M., Brehm, G., and Guldi, D.M. (2006) Angew. Chem. Int. Ed., 45, 4478-4482.

75 (a) Li, H., Martin, R.B., Harruff, B.A., Carino, R.A., Allard, L.F., and Sun, Y.-P. (2004) Adv. Mater., 16, 896-900;

(b) Baskaran, D., Mays, J.W., Zhang, X.P., and Bratcher, M.S. (2005) J. Am. Chem. Soc., 127, 6916-6917.

76 (a) Van Lier, G., Ewels, C.P., Zuliani, F., De Vita, A., and Charlier, J.-C. (2005) J. Phys. Chem. B, 109, 6153-6158;

(b) Lee, Y.-S. (2007) J. Fluorine Chem., 128, 392-403. 
77 Zeng, L., Zhang, L., and Barron, A.R. (2005) Nano Lett., 5, 2001-2004.

78 (a) Zhang, L., Zhang, J., Schmandt, N., Cratty, J., Khabashesku, V.N., Kelly, K.F., and Barron, A.R. (2005) Chem. Commun., 5429-5431; (b) Zhang, J., Zhang, L., Khabashesku, V.N., Barron, A.R., and Kelly, K.F. (2008) J. Phys. Chem. C, 112, 12321-12325.

79 Bahr, J.L., Yang, J., Kosynkin, D.V., Bronikowski, M.J., Smalley, R.E., and Tour, J.M. (2001) J. Am. Chem. Soc., 123, 6536-6542.

80 (a) Bahr, J.L. and Tour, J.M. (2001) Chem. Mater., 13, 3823-3824; (b) Dyke, A. and Tour, J.M. (2003) Nano Lett., 3, 1215-1218.

81 Holzinger, M., Vostrowsky, O., Hirsch, A., Hennrich, F., Kappes, M., Weiss, R., and Jellen, F. (2001) Angew. Chem. Int. Ed., 40, 4002-4005.

82 Pastine, S.J., Okawa, D., Kessler, B., Rolandi, M., Llorente, M., Zettl, A., and Frechet, J.M.J. (2008) J. Am. Chem. Soc., 130, 4238-4239.

83 Ashcroft, J.M., Hartman, K.B., Mackeyev, Y., Hofmann, C., Pheasant, S., Alemany, L.B., and Wilson, L. (2006) Nanotechnology, 17, 5033-5037.

84 Delgado, J.L., de la Cruz, P., Langa, F., Urbina, A., Casado, J., and Lopez Navarrete, J.T. (2004) Chem. Commun., 1734-1735.

85 Tagmatarchis, N. and Prato, M. (2004) J. Mater. Chem., 14, 437-439.

86 Prato, M., Kostarelos, K., and Bianco, A. (2008) Acc. Chem. Res., 41, 60-68.

87 Georgakilas, V., Tagmatarchis, N., Pantarotto, D., Bianco, A., Briand, J.-P., and Prato, M. (2002) Chem. Commun., 3050-3051.

88 Pantarotto, D., Singh, R., McCarthy, D., Erhardt, M., Briand, J.-P., Prato, M., Kostarelos, K., and Bianco, A. (2004) Angew. Chem. Int. Ed., 43, 5242-5246.

89 Singh, R., Pantarotto, D., Lacerda, L. Pastorin, G., Klumpp, C., Prato, M., Bianco, A., and Kostarelos, K. (2006) Proc. Natl. Acad. Sci. USA, 103, 3357-3362.

90 Wu, W., Wieckowski, S., Pastorin, G., Benincasa, M., Klumpp, C., Briand, J., Gennaro, R., Prato, M., and Bianco, A.
(2005) Angew. Chem. Int. Ed., 44,

6358-6362.

91 Pastorin, G., Wu, W., Wieckowski, S., Briand, J.-P., Kostarelos, K., Prato, M., and Bianco, A. (2006) Chem. Commun., 1182-1184.

92 Graupner, R., Abraham, J., Wunderlich, D., Vencelova, A., Lauffer, P., Roehrl, J., Hundhausen, M., Ley, L., and Hirsch, A. (2006) J. Am. Chem. Soc., 128, 6683-6689.

93 Syrgiannis, Z., Gebhardt, B., Dotzer, C., Hauke, F., Graupner, R., and Hirsch, A. (2010) Angew. Chem. Int. Ed., 49, 3322-3325.

94 For recent reviews, see (a) Rao, C.N.R., Sood, A.K., Subrahmanyam, K.S., and Govindaraj, A. (2009) Angew. Chem. Int. Ed., 48, 7752-7777; (b) Allen, M.J., Tung, V.C., and Kaner, R.B. (2010) Chem. Rev., 110, 132-145; (c) Dreyer, D.R., Park, S., Bielawski, C.W., and Rodney, S.R. (2010) Chem. Soc. Rev., 39, 228-240; (d) Ping Loh, K., Bao, Q., Ang, P.K., and Yang, J. (2010) J. Mater. Chem., 20, 2277-2289.

95 Van Noorden, R. (2011) Nature, 469, 14-16.

96 Baughman, R.H., Zakhidov, A.A., and de Heer, W.A. (2002) Science, 297, 787-792.

97 Hernandez, Y., Nicolosi, V., Lotya, M., Blighe, F.M., Sun, Z., De, S., McGovern, I.T., Holland, B., Byrne, M., Gun'ko, Y.K., Boland, J.J., Niraj, P., Duesberg, G., Krishnamurthy, S., Goodhue, R., Hutchison, J., Scardaci, V., Ferrari, A.C., and Coleman, J.M. (2008) Nat. Nanotechnol., 3, 563-568.

98 Niyogi, S., Bekyarova, E., Itkis, M.E., McWilliams, J.L., Hamon, M.A., and Haddon, R.C. (2006) J. Am. Chem. Soc., 128, 7720-7721.

99 Lomeda, R., Doyle, C.D., Kosynkin, D.V., Hwang, W.-F., and Tour, J.M. (2008) J. Am. Chem. Soc., 130, 16201-16206.

100 Quintana, M., Spyrou, K., Grelczak, M., Browne, W.R., Rudolf, P., and Prato, M. (2010) ACS Nano, 4, 3527-3533.

101 Economopoulos, S.P., Rotas, G., Miyata, Y., Shinohara, H., and Tagmatarchis, N. (2010) ACS Nano, 4, 7499-7507. 
102 Subrahmanyam, K.S., Ghosh, A., Gomathi, A., Govindaraj, A., and Rao, C.N.R. (2009) Nanosci. Nanotechnol. Lett., 1, 28-31.

103 Liu, N., Luo, F., Wu, H., Liu, Y., Zhang, C., and Cheng, J. (2008) Adv. Funct. Mater., 18, 1518-1525.

104 Mack, J.J., Viculis, L.M., Luoh, A.A.R., Yang, G., Hahn, H.T., Ko, F.K., and Kaner, R.B. (2005) Adv. Mater., 17, 77-80.

105 Das, B., Prasad, K.E., Ramamurty, U., and Rao, C.N.R. (2009) Nanotechnology, 20, 125705.

106 Ramanathan, T., Abdala, A.A., Stankovich, S., Dikin, D.A., Alonso, M.H., Piner, R.D., Adamson, D.H., Schniepp, H.C., Chen, X., Ruoff, R.S., Nguyen, S.T., Aksay, I.A., Prud-Homme, R.K., and Brinson, L.C. (2008) Nat. Nanotechnol., 3, 327-331.

107 Bai, H., Xu, Y., Zhao, L., Li, C., and Shi, G. (2009) Chem. Commun., 1667-1669.

108 Zu, S.-Z. and Han, B.-H. (2009) J. Phys. Chem. C, 113, 13651-13657.

109 Bao, Q., Zhang, H., Wang, Y., Ni, Z., Yan, Y., Shen, Z.X., Loh, K.P., and Tang, D.Y. (2009) Adv. Funct. Mater., 19, 3077-3083.
110 Xu, X.Y., Bai, H., Lu, G.W., Li, C., and Shi, G.Q. (2008) J. Am. Chem. Soc., 130, 5856-5857.

11 Su, Q., Pang, S., Alijani, V., Li, C., Feng, X., and Müllen, K. (2009) Adv. Mater., 21, 3191-3195.

112 Wang, Y., Chen, X., Zhong, Y., Zhu, F., and Loh, K.P. (2009) Appl. Phys. Lett., 95, 063302.

113 (a) Das, B., Voggu, R., Rout, C.S., and Rao, C.N.R. (2008) Chem. Commun., 5155-5157; (b) Voggu, R., Das, B., Rout, C.S., and Rao, C.N.R. (2008) J. Phys. Condens. Matter., 20, 472204.

114 Manna, A.K. and Pati, S.K. (2009) Chem. Asian J., 4, 855-860.

115 Subrahmanyam, K.S., Voggu, R., Govindaraj, A., and Rao, C.N.R. (2009) Chem. Phys. Lett., 472, 96-98.

116 Barja, S., Garnica, M., Hinarejos, J.J., Vázquez de Parga, A.L., Martín, N., and Miranda, R. (2010) Chem. Commun., 46, 8198-8200.

117 Kozhemyakina, N.V., Englert, J.M., Yang, G., Spiecker, E., Schmidt, C.D., Hauke, F., and Hirsch, A. (2010) Adv. Mater., 22, 5483-5487. 